\title{
IIII! CROP \& PASTURE

Forage and grain yield of common buckwheat in Mediterranean conditions: response to sowing time and irrigation

\begin{tabular}{|r|l|}
\hline Journal: & Crop \& Pasture Science \\
\hline Manuscript ID & CP16091.R1 \\
\hline Manuscript Type: & Research paper \\
\hline Date Submitted by the Author: & n/a \\
\hline Complete List of Authors: & $\begin{array}{l}\text { Mariotti, Marco; University of Pisa, Veterinary science } \\
\text { Masoni, Alessandro; University of Pisa, Agriculture, Food and Environment } \\
\text { Arduini, Iduna; University of Pisa, Agriculture, Food and Environment }\end{array}$ \\
\hline & Alternative crops, Dry matter production, Grain yield, Sowing time \\
\hline
\end{tabular}

SCHOLARONE ${ }^{m}$

Manuscripts 


\section{Forage and grain yield of common buckwheat in Mediterranean}

\section{2 conditions: response to sowing time and irrigation}

3

4 Marco Mariotti $^{A, C}$, Alessandro Masoni $^{B}$, Iduna Arduini $^{B}$

5

6 A Dipartimento di Scienze Veterinarie, viale delle Piagge 2, 56124 Pisa, Italy.

$7 \quad$ B Dipartimento di Scienze Agrarie, Alimentari e Agroambientali, via del Borghetto 80, 56124

8 Pisa,

$9 \quad$ c Corresponding author. E-mail: marco.mariotti@unipi.it.

10

11 Running title: buckwheat for forage and grain

12 
1 Abstract. With the view to extending the cultivation of common buckwheat to Mediterranean

2 environments, we investigated the responses of two varieties to three sowing times, early

3 spring, late spring and late summer, in rainfed and irrigated conditions. Plants were harvested

4 at two ripening stages for forage production and at maturity for grain yield. The eultural-crop

5 cycle lasted 82-88 days independent of sowing time, while the thermal time was

6 approximately $1000{ }^{\circ} \mathrm{Cd}$ in early spring and late summer sowings, and $1200{ }^{\circ} \mathrm{Cd}$ when sown

7 in late spring. Forage yield increased up to $75 \%$ between ripening stages. Early spring was the

8 best sowing time for forage $\left(4 \mathrm{tha}^{-1} \mathrm{DW}\right)$ and grain yield $\left(2 \mathrm{tha}^{-1} \mathrm{DW}\right)$ in rainfed conditions.

9 Late spring sowings give the highest forage yield when irrigated $\left(6 \mathrm{tha}^{-1} \mathrm{DW}\right)$, but were not

10 suitable for producing grain, for the adverse effect of high summer temperatures on seed set

11 and seed filling. Late summer sowings produced acceptable grain yield (1.5 $\left.\mathrm{t} \mathrm{ha} \mathrm{h}^{-1} \mathrm{DW}\right)$,

12 whereas short days and low temperatures limited forage production. Thus, in Mediterranean

13 environments, buckwheat could be profitably introduced as a minor summer crop, sown in

14 early spring for grain production and in late spring for forage production.

16 Additional keywords: alternative crops, dry matter production, grain yield, sowing time. 


\section{$1 \quad$ Introduction}

2 Common buckwheat (Fagopyrum esculentum Moench.), hereafter referred to as buckwheat, is

3 a dicotyledonous annual herb of the family Polygonaceae that was cultivated from ancient

4 times as pseudocereal crop. The stem is erect with a variable branching, and bears one leaf per

5 node. Inflorescences develop in the leaf axils and at the end of both the main stem and

6 branches. Each plant produces a lot of white to pink flowers, but only a few develop into

7 dark-hulled triangular achenes, containing one starch-filled seed (Marshall 1980; Halbrecq et

8 al. 2005).

9 The species originates from the north-west corner of the Yunnan province of China (25-

$1030^{\circ} \mathrm{N}$ ), which is a vast plateau in the Himalayan foothills, where it grows from 500 to $2,500 \mathrm{~m}$

11 above sea level (Campbell 1997). Human consumption of buckwheat fruits dates back to

12 prehistory and, in the first millennium BC, its cultivation diffused from China to Russia and

13 Ukraine. Buckwheat became established in the rest of Europe in the Middle Ages, both as a

14 summer crop in rotation with rye, or on very poor soils, or as a pioneer species on new

15 farmland. The introduction of maize and potato from the new world and the diffusion of

16 higher yielding cereals, such as wheat and barley, caused a rapid decline in buckwheat

17 cultivation, so that in the $19-20^{\text {th }}$ centuries its cropping was associated with poverty and

18 hunger (Körber-Grohne 1987; Ahmed et al. 2014).

19 In recent years there has been renewed interest in buckwheat cultivation, driven by the

20 rising demand for its products. Buckwheat fruit is generally milled to obtain gluten-free flour,

21 which can be consumed by people affected by celiac disease (Alvarez-Jubete et al. 2010;

22 Kaur et al. 2015). This flour possesses higher protein content and a better biological value

23 compared to wheat and rice, due to the higher proportion of the amino acids lysine and

24 arginine (Ratan and Kothiyal 2011; Zhang et al. 2012). The entire fruit is used to produce

25 beer and to feed poultry and pigs (Körber-Grohne 1987). 
1 Buckwheat leaves and young sprouts are consumed fresh as vegetables, or dried to

2 prepare tea, and the entire buckwheat plant contains a variety of compounds that can be used

3 to produce nutraceutical preparations and functional foods (Li and Zhang 2001; Baumgertel et

4 al. 2010). It is also rich in rutin, a flavonoid employed in the prevention and treatment of

5 chronic cardiovascular diseases. Its potential as green and conserved forage and as a source of

6 nectar for honey bees has also been investigated (Omidbaigi and De Mastro 2004;

7 Amelchanka et al. 2010; Kälber et al. 2012; Mariotti et al. 2015). However, along with its

8 beneficial nutrients and phytochemicals, buckwheat also contains fagopyrin, which is a photo-

9 sensitive substance, as well as compounds that can cause allergic reactions (Stojilkovski et al.

10 2013; Ahmed et al. 2014).

11 Buckwheat grows best in cool and humid conditions, and the optimal temperature range

12 for flowering and fruit maturation is $17-19{ }^{\circ} \mathrm{C}$ (Marshall 1980). Ecotypes differ in their

13 sensitivity to photoperiod (Angus et al. 1982; Cawoy et al. 2009), however buckwheat is

14 generally considered a non-specific short day crop (Hao et al. 1995). The crop cycle is quite

15 short, lasting 9-12 weeks, and it needs approximately 1,200 GDD, with a base temperature of

$165{ }^{\circ} \mathrm{C}$, to reach fruit maturity (Edwardson 1995; Ahmed et al. 2014). Buckwheat is thus

17 generally grown in cool temperate and even sub-arctic regions, as a minor summer crop sown

18 in May-June, or later, after the harvest of wheat and barley. However, in subtropical regions it

19 can also be grown as a second crop sown in late summer or autumn (Angus et al. 1982;

20 Amelchanka et al. 2010).

21 The leading buckwheat producers are China, Russia, Ukraine, France, and the USA

22 (FAOSTAT 2015). The yield is highly variable, with a maximum grain production close to $3 \mathrm{t}$

$23 \mathrm{ha}^{-1}$ in France. The short crop cycle and the non-specific response to day length could

24 facilitate the introduction of buckwheat cultivation into new geographical areas, with greatest

25 potential in multiple cropping systems (Angus et al. 1982). In Italy, buckwheat was

26 traditionally cultivated as a summer crop for flour production in restricted Alpine and 
1 Apennine areas. Its introduction in Mediterranean environments, as the main or second crop

2 with a sowing time between early spring and late summer, would enable marginal lands to be 3 exploited and increase farm biodiversity (Tallarico et al. 2008). However, shifts from 4 conventional sowing times could affect both forage and grain production, since buckwheat is 5 sensitive to low temperatures at establishment and to high temperatures and water stress at 6 flowering and grain set (Slawinska and Obendorf 2001; Taylor and Obendorf 2001; Ahmed et 7 al. 2014). Plants would also be exposed to a variety of day lengths, which could influence 8 growth patterns and seed set (Michiyama et al. 2005). In Mediterranean climates, high 9 temperatures and limited water availability could negatively affect buckwheat crops in 10 summer, but also in late spring and early autumn in warm and dry years. To the best of our 11 knowledge, no data are available on either buckwheat cultivation in plain areas with a typical 12 Mediterranean climate or on its response to irrigation.

13 In order to assess the best sowing time for forage and grain production in a typical 14 Mediterranean environment, we cultivated buckwheat in a plain area of central Italy. The 15 responses of two varieties to three sowings, performed in early and late spring and in late 16 summer, were investigated in rainfed and irrigated conditions. Irrigation was applied to 17 evaluate whether an additional water supply could increase yield and ameliorate the adverse effect of high temperatures. Since the stage of highest biomass accumulation is not well defined in buckwheat, forage harvest was performed at two stages of phasic development.

\section{Materials and methods}

22 Experimental site

23 The experiment was carried out in 2012 and 2013 at the Department of Agriculture, Food and

24 Environment of the University of Pisa, Italy, which is located at a distance of approximately 4

$25 \mathrm{~km}$ from the sea $\left(43^{\circ} 40^{\prime} \mathrm{N}, 10^{\circ} 19^{\prime} \mathrm{E}\right)$ and is $1 \mathrm{~m}$ above sea level. The climate of the area is hot- 
1 summer Mediterranean, with mean annual maximum and minimum daily air temperatures of

$220.2^{\circ} \mathrm{C}$ and $9.5^{\circ} \mathrm{C}$, respectively, and a mean rainfall of $971 \mathrm{~mm}$ per year.

3 The main physical and chemical properties of the soil were $51.1 \%$ sand $(2 \mathrm{~mm}-0.05$

$4 \mathrm{~mm}), 38.6 \%$ silt $(0.05 \mathrm{~mm}-0.002 \mathrm{~mm}), 10.3 \%$ clay $(\varnothing<0.002 \mathrm{~mm}), 8.2 \mathrm{pH}, 22.6 \mathrm{~g} \mathrm{~kg}^{-1}$

5 organic matter (Walkley and Black method), $14.2 \mathrm{~g} \mathrm{~kg}^{-1}$ total $\mathrm{CaCO}_{3}$ (Scheibler method), 0.91

$6 \mathrm{~g} \mathrm{~kg}^{-1}$ total nitrogen (Kjeldhal method), $10.2 \mathrm{mg} \mathrm{kg}^{-1}$ available P (Olsen method), and 162.4

$7 \mathrm{mg} \mathrm{kg}{ }^{-1}$ available $\mathrm{K}$ (ammonium acetate test method). Field capacity and permanent wilting

8 point were determined with the pressure chamber method at 33 and $1500 \mathrm{kPa}$ soil water

9 tension, respectively, and were $23.1 \%$ and $10.3 \%$.

11 Treatments and experimental design

12 In each year, treatments involved two buckwheat (Fyagopyrum esculentum Moench)

13 varieties, three sowing times, and two irrigation levels. We also compared two harvest stages

14 for forage production. The commercial varieties Bamby and Lileja were chosen, because of

15 their high and reasonably stabile grain yield and their wide cultivation throughout Europe

16 (Brunori et al. 2006; Kälber et al. 2012). Sowing times were early spring (ESp), late spring

17 (LSp) and late summer (LSu). Early spring, i.e. around mid April, was chosen as the earliest

18 period that escapes spring frost in central Italy. Late spring, i.e. end of May, is the

19 conventional sowing time for buckwheat in temperate climates (Edwardson 1995; Kalinova

20 and Dadakova 2013), and late summer, i.e. beginning of September, is the earliest sowing

21 period escaping summer drought. The sowing dates for the two years are reported in Table 1.

22 Irrigation treatments were rainfed and $100 \%$ replacement of the estimated evapotranspiration.

23 In order to estimate the optimal stage for forage yield, forage harvests were performed at

24 peak full flowering, when plant growth is presumed to stop (Cawoy et al. 2009), and at the

25 beginning of fruit ripening, just prior to the onset of senescence. Following the growth scale

26 of Arduini et al. (2016), these stages were identified with the appearance of 1-2 green achenes 
1 at the base of the first inflorescence formed on the plant (stage 70 - First Green Achenes) and

2 with the ripening of these achenes (stage 85 - First Brown Achenes). For grain yield, plants

3 were harvested at maturity, when all achenes were dark brown or aborted (stage 88, Arduini 4 scale).

5 In both years, the experiment was arranged in a split-split-plot design with three 6 replicates. Sowing date was the main plot factor, irrigation treatment was the sub-plot factor, 7 and variety was the sub-sub-plot factor. Sub-sub-plot dimensions were 5 by $9 \mathrm{~m}$, each 8 separated by $4 \mathrm{~m}$. The three harvests were performed within sub-sub-plots on randomly 9 chosen sample areas of $1 \times 1 \mathrm{~m}$.

\section{Crop management}

12 In both years, the preceding crop was rapeseed. Soil preparation consisted in medium depth 13 ploughing $(30 \mathrm{~cm})$, carried out in October 2011 and 2012. Final seed bed preparation was 14 carried out just prior to sowing by harrowing twice, with a disc harrow, and with a rotating 15 harrow. Buckwheat was sown with $15-\mathrm{cm}$ row spacing and with a density of 200 viable seeds 16 per $\mathrm{m}^{2}$. Nitrogen, phosphorous and potassium fertilisers were applied at rates of 40,44 and 83

$17 \mathrm{~kg} \mathrm{ha}^{-1}$, respectively as urea, triple mineral phosphate and potassium sulphate. Nitrogen was applied just before seeding, while $\mathrm{P}$ and $\mathrm{K}$ were applied before tillage.

19 The soil profile was close to field capacity at planting and, after crop emergence,

20 irrigation lines were permanently installed above ground in inter-rows. Starting from the stage

21 of first true leaf unfolded (stage 11, Arduini et al. 2016), water was distributed daily by drip 22 irrigation ( 1 dripper per metre) and the flow application rate was $4 \mathrm{~L} \mathrm{~h}^{-1} \mathrm{~m}^{-1}$ of tubing. The 23 amount of water given daily was designed so that rainfall plus irrigation replaced the soil 24 moisture lost through evapotranspiration. The potential evapotranspiration $\left(E_{0}\right)$ of the 25 previous day was estimated from Class A pan evaporation. Actual evapotranspiration was 26 calculated as $E=k c \times E_{0}$, where $k c$ is the crop coefficient. Because $k c$ values of buckwheat 
1 are not known, we used those reported for wheat (Doorembos and Pruit 1977). Accordingly,

$2 k c$ values increased from 0.3 at 10 days after emergence to 1.15 at the first brown achenes 3 stage, and declined to 0.25 at maturity. As a whole, 183, 240 and $55 \mathrm{~mm}$ irrigation were 4 supplied, respectively, to ESp, LSp and LSu in 2012, and 193, 232 and $50 \mathrm{~mm}$ in 2013. No 5 pest infestation was detected during the cultivation period, and weed cover was very low up to 6 the end of flowering.

\section{$8 \quad$ Measurements}

9 For the entire period of the research, the minimum and maximum daily temperatures and 10 rainfall were obtained from a weather station located at about $100 \mathrm{~m}$ from the experimental 11 site. Cumulated rainfall from April to November was 671 in 2012 and 468 in 2013, which was

12 higher and lower, respectively, than the preceding ten-year average $(573 \mathrm{~mm})$, by 13 approximately $17 \%$ (Fig. 1). Over the same period, the mean temperature was $18.7^{\circ} \mathrm{C}$ in both 14 years, which was slightly higher than that of the previous 10 years $\left(17.9^{\circ} \mathrm{C}\right)$, primarily due to 15 the higher temperature in the autumn. Day length increased from 12:46 h to 15:27 $\mathrm{h}$ between 161 April and 21 June, and then decreased to 9:12 $\mathrm{h}$ on 30 November (NOAA 2016).

17 Thermal time for buckwheat was calculated as the sum of heat units measured in growing degree-days $\left(\mathrm{GDD},{ }^{\circ} \mathrm{Cd}\right)$, as GDD $=((\operatorname{Tmax}+\mathrm{Tmin}) / 2)-\mathrm{Tb}$. In the formula, Tmax and Tmin are the daily maximum and minimum air temperatures, and $\mathrm{Tb}$ is the base temperature below which no significant crop development occurs. If $\mathrm{Tmin}<\mathrm{Tb}$ then $\mathrm{Tmin}=\mathrm{Tb}$ was also

21 incorporated into the equation. An upper threshold temperature (Tut), above which crop 22 development is negatively affected, was also incorporated, i.e. if Tmax $>$ Tut then Tmax $=$ 23 Tut (McMaster and Wilhelm 1997). Base temperature and Tut were set respectively at $5{ }^{\circ} \mathrm{C}$ 24 and $25^{\circ} \mathrm{C}$ following Edwardson (1995).

25 At each harvest, plants were manually cut at ground level, counted and measured to 26 determine the height. There were approximately 130 plants $\mathrm{m}^{-2}$, without significant 
1 differences among treatments (data were not reported). At forage harvests, plants were

2 separated into leaves, stems and inflorescences, including developing achenes. At maturity, 3 plants were separated into achenes and straw, which consisted of stems, leaves and 4 inflorescence axes. The mean achene weight and harvest index (HI) were also determined. All 5 plant parts were oven dried at $65^{\circ} \mathrm{C}$ to constant weight for dry weight determination.

\section{$7 \quad$ Statistical analysis}

8 The results were subjected to analysis of variance (ANOVA) separately for forage and grain 9 production. For the forage, the main effects of year, sowing date, irrigation, variety, harvest 10 stage, and their interactions were tested. For the grain, we tested the main effects of year, 11 sowing date, irrigation, variety, and their interactions. The combined analysis over years was 12 conducted after verifying the homogeneity of error variances by the chi-square test. The 13 CoStat statistical package (version 6.4, CoHort Software, CA, USA) was used, and, in all 14 analyses, the year and imposed treatments were considered as fixed effects. Significantly 15 different means were separated at the 0.05 probability level by the least significant difference 16 test (Steel et al. 1997).

\section{Results}

Climate conditions

20 The year mean effect and all interactions of year with other treatments were not significant for

21 any of the measured or calculated parameters, probably because between-year differences in 22 temperature and rainfall were very low. Only LSu plants received 39\% more rainfall in 2012

23 than in 2013, but close to the end of the crop cycle (Fig. 1). Accordingly, all data are 24 presented as averaged over years.

25 Climate conditions experienced by buckwheat plants differed markedly in response to 26 sowing time. Cumulated rainfall over the entire growth cycle was 367, 153 and $35 \mathrm{~mm}$ for 
1 LSu, ESp and LSp plants, respectively (Table 1). Mean temperature ranged from 12 to $24{ }^{\circ} \mathrm{C}$

2 in ESp, from 15 to $25^{\circ} \mathrm{C}$ in $\mathrm{LSp}$ and from 6 to $23{ }^{\circ} \mathrm{C}$ in $\mathrm{LSu}$, which corresponded to a mean

3 temperature calculated over the entire eultural-crop cycles of 18,22 and $17{ }^{\circ} \mathrm{C}$, respectively

4 (Fig. 1). Average day length was 14:42 h in ESp, 15:06 h in LSp and 11:00 h in LSu.

5

$6 \quad$ Phasic development

7 The duration of growth phases was affected by sowing time but not by irrigation or variety.

8 Calculated in days, the time to reach the green achenes stage was approximately 38 days in

$9 \mathrm{LSp}$ and $\mathrm{LSu}$, and 50 days in ESp, whereas a further 13-15 days were needed to reach the

10 brown achenes stage in all sowings (Table 1). The period from the first brown achenes stage

11 to crop maturity increased with the delay in sowing, which was 23,28 and 36 days in ESp,

12 LSp and LSu, respectively. The length of the entire growth cycle thus did not vary greatly in

13 response to sowing date, which was between 82 and 88 days.

14 Calculated in thermal units, the time to reach the first green achenes stage was 15 approximately $530{ }^{\circ} \mathrm{Cd}$ in all sowings (Table 1). Thereafter, ESp and LSu plants needed 16 approximately further $170{ }^{\circ} \mathrm{Cd}$ to reach the first brown achenes stage and an additional 330

$17{ }^{\circ} \mathrm{Cd}$ for achene maturity, while LSp plants required $35 \%$ and $45 \%$ more thermal units, 18 respectively. As a result, the thermal time cumulated by buckwheat from sowing to maturity 19 was slightly higher than $1000^{\circ} \mathrm{Cd}$ in $\mathrm{ESp}$ and LSu, and close to $1200^{\circ} \mathrm{Cd}$ in LSp.

21 Forage production

22 At both harvests, the dry biomass of buckwheat forage decreased with the delay in sowing 23 from early spring to late summer in rainfed conditions (Fig. 2). However, at the green achenes 24 stage, the dry biomass decreased progressively by $33 \%$, whereas, at the brown achenes stage, 25 the decrease was approximately $41 \%$ in LSp and LSu compared to ESp. Up to the stage of 26 first green achenes, irrigation did not affect forage production in ESp and LSu, while 
1 irrigation increased forage production by $91 \%$ in LSp. After the first forage harvest, the effect

2 of irrigation was still not significant in ESp, but was much more pronounced in LSp $(+180 \%)$ 3 and $\mathrm{LSu}(+28 \%)$.

4 Forage dry weight always increased from the first green to the first brown achene stages, 5 however increments differed greatly according to sowing time and irrigation (Fig. 2). The 6 lowest increments were recorded in rainfed plants of LSp and LSu, (approximately $50 \mathrm{~g} \mathrm{~m}^{-2}$ ), 7 and the highest increments were in irrigated plants of LSp (approximately $300 \mathrm{~g} \mathrm{~m}^{-2}$ ). As a 8 result, maximum forage yield was obtained in LSp with the aid of irrigation $\left(5.9 \mathrm{tha}^{-1}\right)$, and in 9 ESp in rainfed conditions $\left(3.8 \mathrm{tha}^{-1}\right)$.

10 Patterns of plant height matched those of forage yield, indicating that changes in forage 11 production were essentially due to changes in plant size (Fig. 2). Maximum height was 111 $12 \mathrm{~cm}$ in LSp irrigated plants, while it was only 72 and $60 \mathrm{~cm}$ in plants of ESp and LSu.

13 At both forage harvests, leaf and stem dry weight changed in response to treatments, but 14 the response to irrigation was more pronounced in stems than in leaves. In fact, at the second 15 harvest, water supply increased leaf biomass by $20 \%$ in LSu and by $150 \%$ in LSp, while water 16 supply increased the biomass of stems by $35 \%$ and $233 \%$, respectively (Table 2). The 17 response of inflorescence biomass did not match that of leaves and stems. At the first green 18 achene stage, it did not differ significantly among sowing dates in rainfed conditions and was 19 increased by irrigation only in LSp. At the first brown achene stage, in rainfed conditions, 20 inflorescence biomass still did not differ significantly between ESp and LSu, but was much 21 lower in LSp. Irrigation increased dry weight of inflorescences in all sowings but increments 22 were much higher in LSp, so that inflorescence biomass decreased in the order LSp $>$ LSu $>$ 23 ESp.

24 Plant parts changed with different patterns between forage harvests. Leaf biomass did not 25 increase except in LSp irrigated plants, whereas stem biomass always increased in ESp, only 26 when irrigated in LSp, and never in LSu (Table 2). Due to achene development, inflorescence 
1 biomass increased markedly between harvests in all treatments, but increments were more 2 pronounced in irrigated plants. The different growth patterns of leaves, stems and 3 inflorescences and their different responses to treatments affected partitioning in forage. The 4 most striking difference was in the proportion of inflorescences at the first brown achene 5 stage, which was approximately $28 \%$ in ESp and LSp and 50\% in LSu, irrespective of 6 irrigation treatments (data not shown).

7 Varieties responded similarly to treatments, however Bamby was approximately $8 \mathrm{~cm}$ 8 taller and produced $7 \%$ more forage than Lileja, averaged over years, sowing times, irrigation

9 treatment and stage of forage harvest. The higher forage yield was due to the higher stem 10 biomass, since leaf biomass was the same and inflorescence biomass was also higher in Lileja 11 at the second harvest (Table 3). This slightly affected partitioning within forage, with a higher 12 proportion of stems in Bamby than in Lileja (56\% vs 53\%) and a higher proportion of 13 inflorescences in Lileja than in Bamby (24\% vs 22\%), averaged over harvests.

\section{Grain yield}

16 Grain yield differed markedly in response to sowing time, and the highest values of $224 \mathrm{~g} \mathrm{~m}^{-2}$ 17 were achieved with ESp, irrespective of irrigation treatments (Fig. 3). In LSp, grain yield was 18 very low $\left(24 \mathrm{~g} \mathrm{~m}^{-2}\right)$ in rainfed conditions, and increased to only $91 \mathrm{~g} \mathrm{~m}^{-2}$ with the aid of 19 irrigation. In LSu, grain yield was approximately $150 \mathrm{~g} \mathrm{~m}^{-2}$, with a slight positive effect due 20 to irrigation. The number of achenes per plant decreased with the delay in sowing from 63 to 21 approximately 43, but in non-irrigated plants, it fell dramatically in LSp (Fig. 3). Finally, the 22 dry weight of straw, showed similar patterns to grain yield in ESp and LSu, and was 23 approximately $67 \%$ higher in the former than in the latter. In LSp, straw biomass was between 24 the other two sowings in rainfed conditions, and approximately $158 \%$ higher when irrigated 25 (Fig. 3). 
Mean achene weight and harvest index changed in response to sowing time and variety,

2 but were not affected by irrigation. Mean achene weight was $13 \%$ higher and harvest index

3 was 7\% higher in LSu than in ESp, and both parameters were very low in LSp (Table 4). The

4 mean achene weight was by $9 \%$ higher in Lileja than in Bamby, which, however, did not

5 affect grain yield, which was $1.5 \mathrm{t} \mathrm{ha}^{-1}$ in both varieties. In contrast, similar to forage harvests,

6 straw biomass was higher in Bamby (295 vs $261 \mathrm{~g} \mathrm{~m}^{-2}$ ) and, consequently, the harvest index

7 was lower in this variety.

8

\section{Discussion}

10 In our research, buckwheat yielded close to $4 \mathrm{tha}^{-1}$ forage dry matter when sown in early 11 spring in rainfed conditions, and close to $6 \mathrm{tha}^{-1}$ when sown in late spring with the aid of 12 irrigation. The highest grain yield, $2.2 \mathrm{t} \mathrm{ha}^{-1}$, was obtained with the early spring sowing, 13 irrespective of irrigation treatment. Forage yield was higher than obtained in central Europe 14 (Kälber et al. 2012; Kalinova and Dadakova 2013) when irrigated, but slightly lower when 15 rainfed. Otherwise, grain yield was approximately $25 \%$ lower than the best performance of 16 this crop (FAOSTAT 2016), but in line with maximum values obtained in central Europe 17 (Schulte et al. 2005; Kalinova and Dadakova 2013), in Iran (Sobhani et al. 2014), in Japan 18 (Murayama 2001) and in hilly regions in Italy (Brunori et al. 2006). Our results suggest that buckwheat cultivation could be profitably introduced into Mediterranean climate regions, however limited water availability and high temperatures play a crucial role in determining

21 the best sowing time for both grain and forage production. In addition, shifts in sowing time expose plants to a variety of day lengths, which also influence plant growth and phasic 23 development (Michiyama et al. 2005).

24 While the length of the entire growth cycle varied by less than $7 \%$ in response to sowing 25 time, the thermal time was $20 \%$ higher in LSp. The higher value, $1200{ }^{\circ} \mathrm{Cd}$, matches that 26 reported by Edwardson (1995) for buckwheat sown in North Dakota (USA) in May. The 
1 lower thermal time required by ESp and LSu plants confirms the findings of Quinet et al.

2 (2004) that short days cause early apical senescence in buckwheat, and indicates that Bamby

3 and Lileja are sensitive to the photoperiod, showing reduced plant growth in short days. Since

4 day length increased from 13:07 to 15:27 $\mathrm{h}$ in ESp, ranged between 14:01 and 15:27 $\mathrm{h}$ with

5 both increasing and decreasing trends in LSp, and decreased from 13:06 to 9:12 $\mathrm{h}$ in LSu, this

6 suggests that buckwheat plants required a longer growth period and more thermal time when

7 they were grown for the entire crop cycle with a longer day length than $14 \mathrm{~h}$ and were

8 exposed to $15 \mathrm{~h}$ day length at initial growth stages (Arduini et al. 2016).

9 In addition to short days, in ESp and LSu, also low temperatures could have contributed

10 to the reduced plant growth. Indeed, averaged over years, mean temperatures were below the

11 optimal range for buckwheat growth of $18-23{ }^{\circ} \mathrm{C}$ (Cawoy et al. 2009) for more than half the

12 eulurat crop cycle in ESp and LSu, but only for approximately one week in LSp. Thus, late

13 spring and summer sowings match the best photothermal conditions for buckwheat forage

14 production in a Mediterranean environment. However, the amount of rainfall received by the

15 LSp plants was markedly lower than $90 \mathrm{~mm}$, which is the threshold for obtaining an

16 acceptable forage yield of buckwheat (Marshall and Pomeranz 1982), thus the forage yield

17 was higher in ESp than in LSp, in rainfed conditions.

18 Irrigation positively affected stem elongation, with increments of up to $40 \mathrm{~cm}$ in plant

19 height, and increased leaf and inflorescence dry matter more than twofold and increased that

20 of stems over threefold. Irrigation slightly increased forage yield also in LSu, despite the

21 higher rainfall than in ESp. This result indicates that soil moisture at planting, which is much

22 higher in spring than in late summer, is important to sustain buckwheat growth in the initial

23 stages, and that early growth influences final vegetative biomass. Since rainfall patterns in the

24 two years of the research were close to the 10-year average, the present results suggest that

25 irrigation support should be planned when buckwheat is sown in late spring or late summer. 
1 With all sowing dates, plants needed approximately two weeks to pass from the first

2 green to the first brown achene stage. During this period, forage production increased by

3 approximately $75 \%$ in ESp and in irrigated LSp, which was a key factor in terms of the high

4 forage yield obtained with these treatments. Primarily inflorescences and secondly stems

5 contributed to the yield increase between harvests, whereas leaf biomass increased only in

6 irrigated LSp. At the brown achenes stage however, forage had a higher proportion of

7 inflorescences and a lower proportion of leaves, which could influence its nutritional and

8 nutraceutical value. It has in fact been reported that the concentration of total digestible

9 nutrients and polyphenolic substances differs in flowers and leaves of buckwheat (Bystricka

10 et al. 2014; Mariotti et al. 2015), and also changes within plant parts according to growth

11 stage and sowing date (Baumgertel et al. 2010; Sobhani et al. 2014). The nutritional value of

12 buckwheat forage obtained from an early spring sowing was found to be higher at the first

13 brown achene stage than at the first green achene stage, whereas the content in crude protein

14 was lower (Mariotti et al. 2015).

15 In the present research, grain yield responded differently from forage yield to

16 photothermal conditions and water regime, since the highest achene yield was obtained with

17 ESp, and the lowest achene yield was obtained with LSp, irrespective of irrigation treatments.

18 Yield reductions in LSu and LSp were the result of a combination of adverse photothermal

19 conditions and water stress, since they were only partly alleviated by irrigation.

20 In buckwheat, flower production greatly exceeds seed set (Kinet et al. 1985), indicating

21 that reproductive development from flower initiation up to seed maturity is critical for grain

22 yield determination. In our research, the analysis of yield components indicated that the

23 primary cause of poor yield was the low number of seeds per plant, which could be attributed

24 almost entirely to a strong reduction in the seed-set ratio, since inflorescence biomass at the

25 first green achene stage was similar across sowing dates in rainfed conditions and even higher

26 in LSp when irrigated. Arduini et al. (2016) also found that the number of inflorescences per 
1 plant was almost double in plants sown in late spring compared to those sown in early spring,

2 and Quinet et al. (2004) and Kalinova and Dadakova (2013) reported that long days increased

3 flower production. Flower failure has usually been attributed either to internal factors, such as

4 competition between organs for available resources, or to unfavourable external conditions

5 and, in buckwheat, high temperatures and water stress have both been suggested as important

6 factors regulating seed set (Taylor and Obendorf 2001). Slawinska and Obendorf (2001) and

7 Cawoy et al. (2009) found that temperatures exceeding $25^{\circ} \mathrm{C}$, which occurred for several

8 days during the LSp crop cycle, caused flower withering and fruit desiccation, while a 3-day

9 water deficit stress at the beginning of flowering reduced the seed set by up to $50 \%$. Marshall

10 and Pomeranz (1982) also reported that a limited water supply induced early embryo abortion

11 and lighter mature seeds.

12 In our research, LSp plants produced more flowers and achenes when irrigated, however

13 the achenes were very light, suggesting that water supply positively affected the flower and

14 seed set, but not seed filling. Thus, we can state that, in Mediterranean climates, summer

15 temperatures severely limit the achene yield of buckwheat sown in LSp, and that prolonged

16 flowering induced by long days are only partially effective. In fact, according to Slawinska

17 and Obendorf (2001), seeds initiated late in the flowering period fail to fill with seed storage

18 reserves in the embryo and endosperm and scarcely contribute to yield.

19 The lower grain yield obtained with LSu compared to ESp was probably due to the

20 detrimental effect of low temperatures on flowering and, especially, on fruit ripening

21 (Funatsuki et al. 2000; Arduini et al. 2016). Cawoy et al. (2009), reported delayed and

22 reduced flowering for temperatures lower than $15{ }^{\circ} \mathrm{C}$, and fruit abortion for less than $10{ }^{\circ} \mathrm{C}$,

23 and in both years of our research these were the conditions experienced by LSu plants during

24 the reproductive phase. It is worth noting however that neither resources availability nor

25 photothermal conditions appeared to limit seed filling in this season, since we found that

26 mean seed weight was higher in LSu than in ESp plants. 
1 All summarized, the present research highlights that buckwheat is suitable for cultivation

2 in plain regions of Mediterranean Europe for the production of both forage and grain,

3 however the choice of sowing date is crucial for acceptable yields. Early spring was found to

4 be the best sowing time for both forage and grain production in rainfed conditions. However,

5 while soil water from autumn and winter rainfall proved to be sufficient to sustain plant

6 growth in this period, low temperatures and short days can limit vegetative growth and forage

7 yield. To increase forage production, buckwheat should be sown at the end of spring, however

8 irrigation is necessary for crop growth.

9 Our results clearly indicate that, irrespective of water supply, late spring sowings are not

10 suited to grain production in a typical Mediterranean environment, because of the negative

11 effect of high temperatures on flower fertilisation and seed filling. In order to escape high

12 temperatures and drought, buckwheat can also be sown at the end of summer, however short

13 days and low temperatures considerably reduce forage production, while grain yield is

14 acceptable. For late summer sowings, we also suggest that irrigation support should be

15 planned in order to sustain initial plant growth, especially in years with a prolonged summer 16 drought.

17 In Mediterranean climate regions, buckwheat could thus be profitably introduced as a 18 minor summer crop, in early spring, for grain production, and late spring for forage 19 production. Considering that buckwheat has limited requirements in regard of tillage, it could

20 be sown in late spring to obtain a second forage crop after the harvesting of a forage winter

21 cereal. Alternatively, buckwheat could also be sown as a second crop at the end of summer, 22 for grain production.

23 The two varieties that we tested - Bamby and Lileja - responded similarly to treatments, 24 but differed slightly in size and harvest index, so that Bamby might be more suitable for 25 forage, and Lileja for grain. Finally, with all treatments forage yield was higher when '1-2

26 brown achenes are visible at the base of the first inflorescence developed on the main stem' 
1 (stage 85, Arduini scale), which could, therefore, be taken as a reference stage for the harvest

2 of buckwheat forage.

3

4

\section{$5 \quad$ References}

6 Ahmed A, Khalid N, Ahmad A, Abbasi NA, Latif MSZ, Randhawa MA (2014)

7 Phytochemicals and biofunctional properties of buckwheat: a review. The Journal of Agricultural Science 152, 349-369. doi:10.1017/S0021859613000166

Alvarez-jubete L,Arendt EK, Gallagher E (2010) Nutritive value of pseudocereals and their increasing use as functional gluten-free ingredients. Trends in Food Science \& Technology 21, 106-113. doi:10.1016/j.tifs.2009.10.014

Amelchanka SL, Kreuzer M, Leiber F (2010) Utility of buckwheat (Fagopyrum esculentum Moench) as feed: Effects of forage and grain on in vitro ruminal fermentation and performance of dairy cows. Animal Feed Science and Technology 155, 111-121. doi:10.1016/j.anifeedsci.2009.10.007

Angus JF, Mackenzie DH, Myers RJK, Foale MA (1982) Phasic development in field crops. Ill. The pseudocereals, buckwheat and grain amaranth. Field Crops Research 5, 305-318.

Arduini I, Masoni A, Mariotti M 2016. A growth scale for the phasic development of common buckwheat. Acta Agriculturae Scandinavica, Section B 66, 215-228. doi:10.1080/09064710.2015.1087587

Baumgertel A, Loebers A, Kreis W (2010) Buckwheat as a source for the herbal drug Fagopiriherba: rutin content and activity of flavonoid-degrading enzymes during plant development. The European Journal of Plant Science and Biotechnology 4, 82-86.

Brunori A, Brunori A, Baviello G, Marconi E, Colonna M, Ricci M, Mandarino P (2006) Yield assessment of twenty buck-wheat (Fagopyrum esculentum Moench and Fagopyrum 
1 tataricum Gaertn.) varieties grown in central (Molise) and southern Italy (Basilicata and

2 Calabria). Fagopyrum 23, 83-90.

3 Bystricka J, Musilova J, Tomas J, Vollmannova A, Lachman J, Kavalcova P (2014) Changes

4 of polyphenolic substances in the anatomical parts of buckwheat (Fagopyrum esculentum

5 Moench) during its growth phases. Foods 3, 558-568. doi:10.3390/foods3040558

6 Campbell CG (1997) Buckwheat. Fagopyrum esculentum Moench. Promoting the

$7 \quad$ conservation and use of underutilized and neglected crops. 19. Institute of Plant Genetics

8 and Crop Plant Research, Gatersleben/International Plant Genetic Resources Institute,

9 Rome, Italy, ISBN 92-9043-345-0

10 Cawoy V, Ledent JF, Kinet JM, Jacquemart AL (2009) Floral biology of common buckwheat

11 (Fagopyrum esculentum Moench). The European Journal of Plant Science and

12 Biotechnology 3, 1-9.

13 Doorembos J, Pruitt WO (1977) Guidelines for predicting crop water requirements. FAO, 14 paper No. 24, Rome.

15 Edwardson SE (1995) Using growing degree days to estimate optimum windrowing time in 16 buckwheat. In 'Current Advances in Buckwheat Research'. (Eds T Matano, A Ujihara),

17 Proceedings of the Sixth International Symposium on Buckwheat. Shinshu (China), 241829 August 1995, Shinshu University Press, pp. 509-514.

19 FAOSTAT (2015) FAO Statistical Databases. Rome: FAO. Available at: 20 http://faostat.fao.org/ (accessed 31 January 2016).

21 Funatsuki H, Maruyama-Funatsuki W, Fujino K, Agatsuma M (2000) Ripening habit of 22 buckwheat. Crop Science 40, 1103-1108

23 Halbrecq B, Romedenne P, Ledent JF (2005) Evolution of flowering, ripening and seed set in 24 buckwheat (Fagopyrum esculentum Moench): quantitative analysis. European Journal of 25 Agronomy 23, 209-224. 
1 Hao X, Li G, Yang W, Zhou N, Lin R, Zhou M (1995) The difference and classification of

2 light reaction of buckwheat under different treatments of light duration. In 'Current 3 Advances in Buckwheat Research'. (Eds T Matano, A Ujihara), Proceedings of the Sixth

4 International Symposium on Buckwheat. Shinshu (China), 24-29 August 1995, Shinshu

$5 \quad$ University Press, pp. 541-549.

6 Kälber T, Kreuzer M, Leiber F (2012) Silages containing buckwheat and chicory: quality, 7 digestibility and nitrogen utilisation by lactating cows. Archives of animal nutrition 66, 8 50-65. doi: 10.1080/1745039X.2011.630213

9 Kalinova J, Dadakova E (2013) Influence of sowing date and stand density on rutin level in 10 buckwheat. Cereal Research Communications 41, 348-358. doi:10.1556/CRC.2012.0039

11 Kaur M, Sandhu KS, Arora AP, Sharma A (2015) Gluten free biscuits prepared from 12 buckwheat flour by incorporation of various gums: physicochemical and sensory 13 properties. Food Science and Technology 62, 628-632. doi:10.1016/j.lwt.2014.02.039

14 Kinet JM, Sachs RM, Bernier G (1985) The Physiology of Flowering, Vol. 3, The 15 Development of Flowers. CRC Press, Boca Raton, Florida

16 Körber-Grohne U. 1987. Nutzpflanzen in Deutschland. Kulturgeschichte und Biologie 17 [Cultivated plants in Germany. History and biology]. Stuttgart: Theiss Verlag GmbH., pp. $18 \quad 339-349$, ISBN 3-8062-1116-7

19 Li SQ, Zhang QH (2001) Advances in the development of functional foods from buckwheat. 20 Critical Reviews in Food Science and Nutrition 41, 451-464. doi: $21 \quad 10.1080 / 20014091091887$

22 Mariotti M, Andreuccetti V, Tozzi B, Liponi G, Turchi B, Arduini I, Gatta D (2015) Forage 23 production and nutritional characteristics of buckwheat as affected by maturity and 24 conservation method. Agrochimica 59, 137-154. doi: 10.12871/0021857201524 
1 Marshall HG, Pomeranz Y (1982) Buckwheat: description, breeding, production and

2 utilization. In 'Advances in cereal science and technology', (Eds Y Pomeranz), vol. 5, 3 American Association of Cereal Chemists Incorporated, St. Paul, Minnesota, pp. 157-210.

4 Marshall HG (1980) Buckwheat. In 'Hybridization of Crop Plants' (Eds WR Fehr, HH

5 Hadley), American Society of Agronomy, Crop Science Society of America, Madison,

$6 \quad$ USA, pp. $215-224$.

7 McMaster GS, Wilhelm WW (1997) Growing degree-days: one equation, two interpretations.

$8 \quad$ Agricultural and Forest Meteorology 87, 291-300.

9 Michiyama H, Tsuchimoto K, Tani KI, Hirano T, Hayashi H, Campbell CG (2005) Influence

10 of day length on stem growth, flowering, morphology of flower clusters, and seed-set in

11 buckwheat (Fagopyrum esculentum Moench). Plant Prod Science 8, 44-50.

12 doi:10.1626/pps.8.44

13 Murayama S (2001) Effects of Cropping Systems and Fertilizer Application on Grain Yield of 14 Common Buckwheat (Fagopyrum esculentum Moench). Proceedings of the 8th 15 International Symposium on Buckwheat, pp. 157-160.

16 NOAA Sunrise/Sunset Calculator, 2016. Available online at 17 http://www.esrl.noaa.gov/gmd/grad/solcalc/sunrise.html (accessed 15 February 2016).

18 Omidbaigi R, Mastro GDE (2004) Influence of Sowing Time on the Biological Behaviour,

19 Biomass Production, and Rutin Content of Buckwheat (Fagopyrum esculentum Moench).

20 Italian Journal of Agronomy 8, 47-50.

21 Quinet M, Cawoy V, Lefèvre I, van Miegroet F, Jacquemart AL, Kinet JM (2004) 22 Inflorescence structure and control of flowering time and duration by light in buckwheat 23 (Fagopyrum esculentum Moench). Journal of Experimental Botany 55, 1509-1517. 24 doi:10.1093/jxb/erh164

25 Ratan P, Kothiyal P (2011) Fagopyrum esculentum Moench (common buckwheat) edible 26 plant of Himalayas: a review. Asian Journal of Pharmacy and Life Science 1, 426-442. 
1 Schulte auf'm Erley G, Kaula HP, Kruseb M, Aufhammer W (2005) Yield and nitrogen

2 utilization efficiency of the pseudocereals amaranth, quinoa, and buckwheat under

3 differing nitrogen fertilization. European Journal of Agronomy 22, 95-100.

$4 \quad$ doi:10.1016/j.eja.2003.11.002

5 Slawinska J, Obendorf RL (2001) Buckwheat seed set in planta and durlimiting seed set in

6 buckwheat.ing in vitro inflorescence culture: evaluation of temperature and water deficit

7 stress. Seed Science Research 11, 223-233. doi:http://dx.doi.org/10.1079/SSR200178

8 Sobhani MR, Rahmikhdoev G, Mazaheri D, Majidian M (2014) Influence of different sowing

9 date and planting pattern and $\mathrm{N}$ rate on buckwheat yield and its quality. Australian

$10 \quad$ Journal of Crop Science 8, 1402-1414.

11 Steel RGD, Torrie JH, Dickey DA (1997) Principles and procedure of statistics: a biometrical

12 approach. (McGraw-Hill: New York)

13 Stojilkovski K, Glavač NK, Kreft S, Kreft I (2013) Fagopyrin and flavonoid contents in 14 common, Tartary, and cymosum buckwheat. Journal of Food Composition and Analysis

$15 \quad 32,126-130$. doi:10.1016/j.jfca.2013.07.005

16 Tallarico R, Ghiselli L, Romagnoli S, Benedettelli S (2008) Grano saraceno coltura dai molti

17 usi. L'Informatore Agrario 35, 45-47.

18 Taylor DP, Obendorf RL (2001) Quantitative assessment of some factors limiting seed set in

19 buckwheat. Crop Science 41, 1792-1799. doi:10.2135/cropsci2001.1792

20 Zhang ZL, Zhou ML, Tang Y, Li FL, Tang YX, Shao JR, Xue WT, Wu YM (2012) Bioactive

21 compounds in functional buckwheat food. Food Research International 46, 389-395.

22 doi:10.1016/j.foodres.2012.07.035 
Tables

2

Table 1. Duration (days), and accumulated thermal time $\left({ }^{\circ} \mathrm{Cd}\right)$ and rainfall $(\mathrm{mm})$ from sowing to harvests of buckwheat, as affected by sowing time in the two years of the research.

\begin{tabular}{|c|c|c|c|c|c|}
\hline \multirow[b]{2}{*}{ Year } & \multirow[b]{2}{*}{ Sowing time } & \multirow[b]{2}{*}{ Variable } & \multicolumn{3}{|c|}{ Harvest stage } \\
\hline & & & Green achenes & Brown achenes & Maturity \\
\hline \multirow[t]{12}{*}{2012} & Early spring & date & 06 June & 19 June & 11 July \\
\hline & (17 April) & days & 50 & 63 & 85 \\
\hline & & thermal time & 525 & 704 & 1048 \\
\hline & & rainfall & 114.0 & 129.4 & 132.0 \\
\hline & Late spring & date & 02 July & 16 July & 16 August \\
\hline & (24 May) & days & 39 & 53 & 84 \\
\hline & & thermal time & 556 & 777 & 1259 \\
\hline & & rainfall & 21.8 & 22.8 & 26.0 \\
\hline & Late summer & date & 12 October & 25 October & 30 November \\
\hline & (4 September) & days & 38 & 51 & 87 \\
\hline & & thermal time & 548 & 709 & 988 \\
\hline & & rainfall & 100.8 & 137.2 & 425.8 \\
\hline \multirow[t]{12}{*}{2013} & Early spring & date & 27 May & 11 June & 5 July \\
\hline & (8 April) & days & 49 & 64 & 88 \\
\hline & & thermal time & 523 & 701 & 1044 \\
\hline & & rainfall & 119.0 & 148.0 & 150.6 \\
\hline & Late spring & date & 4 July & 19 July & 17 August \\
\hline & (27 May) & days & 38 & 53 & 82 \\
\hline & & thermal time & 506 & 745 & 1211 \\
\hline & & rainfall & 31.6 & 33.2 & 44.8 \\
\hline & Late summer & date & 10 October & 23 October & 27 November \\
\hline & (3 September) & days & 37 & 50 & 85 \\
\hline & & thermal time & 527 & 689 & 1032 \\
\hline & & rainfall & 144.2 & 204.2 & 309.0 \\
\hline
\end{tabular}

6 
1 Table 2. Dry weight of leaves, stems and inflorescences $\left(\mathrm{g} \mathrm{m}^{-2}\right)$ at the first green

2 and first brown achenes stages, as affected by the sowing time $x$ irrigation $x$ stage

3 of harvest interaction. Data are the means- $\underline{\underline{\mathrm{SD}}}$ of two years, two varieties and 4 three replicates.

$5 \quad$ For each plant part, values followed by the same letter are not statistically different for $\mathrm{P} \leq 0.05$.

\begin{tabular}{|c|c|c|c|c|}
\hline \multirow[b]{2}{*}{ Harvest stage } & \multirow[b]{2}{*}{ Irrigation } & \multicolumn{3}{|c|}{ Sowing time } \\
\hline & & Early spring & Late spring & Late summer \\
\hline & & & Leaves & \\
\hline \multirow[t]{2}{*}{ Green achenes } & Rainfed & $65.2 \pm 5.3 \mathrm{c}$ & $47.2 \pm 2.7 \mathrm{~b}$ & $43.6 \pm 3.5 \mathrm{ab}$ \\
\hline & Irrigated & $66.5 \underline{ \pm 5.9} \mathrm{c}$ & $77.3 \underline{\underline{ \pm 8.3}} \mathrm{~d}$ & $43.5 \pm 2.2 \mathrm{ab}$ \\
\hline \multirow[t]{2}{*}{ Brown achenes } & Rainfed & $62.5 \pm \underline{ \pm 4.7} \mathrm{c}$ & $48.0 \pm 2.9 \mathrm{~b}$ & $38.9 \pm \underline{\underline{ \pm 1.9}} \mathrm{a}$ \\
\hline & Irrigated & $63.8 \pm 7.4 \mathrm{c}$ & $\begin{array}{c}94.9 \pm 7.4 \mathrm{e} \\
\text { Stems }\end{array}$ & $46.7 \pm 3.3 b$ \\
\hline \multirow[t]{2}{*}{ Green achenes } & Rainfed & $133.9 \pm 15.2 \mathrm{~d}$ & $99.9 \pm 7.3 \mathrm{bc}$ & $70.3 \pm 7.9 \mathrm{a}$ \\
\hline & Irrigated & $137.9 \pm 8.5 \mathrm{~d}$ & $212.0 \pm 23.4 \mathrm{e}$ & $78.0 \pm 6.6 \mathrm{ab}$ \\
\hline \multirow[t]{3}{*}{ Brown achenes } & Rainfed & $205.6 \pm 12.8 \mathrm{e}$ & $104.8 \pm 9.6 \mathrm{c}$ & $70.3 \pm 2.9 \mathrm{a}$ \\
\hline & Irrigated & $203.5 \pm 25.3 \mathrm{e}$ & $349.2 \pm 32.3 \mathrm{f}$ & $95.1 \pm 6.1 \mathrm{bc}$ \\
\hline & & & Inflorescences & \\
\hline \multirow[t]{2}{*}{ Green achenes } & Rainfed & $21.5 \pm 1.7 \mathrm{a}$ & $27.6 \pm 2.3 \mathrm{a}$ & $32.8 \pm 3.9 \mathrm{ab}$ \\
\hline & Irrigated & $20.6 \pm 1.2 \mathrm{a}$ & $43.7 \pm \underline{\underline{4.3} b}$ & $27.4 \pm 3.1 \mathrm{a}$ \\
\hline \multirow[t]{2}{*}{ Brown achenes } & Rainfed & $101.5 \pm 7.1 \mathrm{~d}$ & $59.1 \pm 5.2 \mathrm{c}$ & $113.2 \pm 7.7 \mathrm{~d}$ \\
\hline & Irrigated & $117.2 \pm 11.1 \mathrm{e}$ & $149.1 \pm 27.7 \mathrm{~g}$ & $133.4 \underline{\underline{ \pm 5.7}} \mathrm{f}$ \\
\hline
\end{tabular}

7

8

9 
1 Table 3. Dry weight of stems and inflorescences, as affected by the 2

3 of two years, three sowing times, two irrigation treatments and

5 Within a column, values followed by the same letter are not

$$
\text { statistically different for } \mathrm{P} \leq 0.05 \text {. }
$$

\begin{tabular}{llcc}
\hline Harvest stage & Variety & $\begin{array}{c}\text { Stems } \\
\left(\mathrm{g} \mathrm{m}^{-2}\right)\end{array}$ & $\begin{array}{c}\text { Inflorescences } \\
\left(\mathrm{g} \mathrm{m}^{-2}\right)\end{array}$ \\
\hline Green achenes & Bamby & $129.6 \underline{\underline{ \pm 22.6} \mathrm{~b}}$ & $30.9 \underline{\underline{ \pm 4.1} \mathrm{a}}$ \\
& Lileja & $113.8 \underline{\underline{ \pm 20.3} \mathrm{a}}$ & $27.3 \underline{\underline{ \pm 3.8}} \mathrm{a}$ \\
Brown achenes & Bamby & $185.3 \underline{\underline{ \pm 43.3} \mathrm{~d}}$ & $104.7 \pm \underline{\underline{ \pm 17.0} \mathrm{~b}}$ \\
& Lileja & $159.2 \underline{\underline{ \pm 36.1} \mathrm{c}}$ & $114.6 \underline{\underline{ \pm 15.8}} \mathrm{c}$ \\
\hline
\end{tabular}

7 
1 Table 4. Mean achene weight and harvest index of buckwheat at

2 maturity, as affected by the mean effects of sowing time and

3 variety. Data are means $\underline{\underline{ \pm S D}}$ of two years, two irrigation treatments, two varieties or three sowing dates, and three replicates.

6 Within a mean effect and column, values followed by the same letter are not statistically different for $\mathrm{P} \leq 0.05$.

\begin{tabular}{|c|c|c|}
\hline Treatment & $\begin{array}{c}\text { Mean achene weight } \\
(\mathrm{mg})\end{array}$ & $\begin{array}{c}\text { Harvest index } \\
(\%)\end{array}$ \\
\hline \multicolumn{3}{|c|}{ Sowing time } \\
\hline Early spring & $22.7 \pm 0.5 \mathrm{a}$ & $48.8 \pm 2.1 \mathrm{a}$ \\
\hline Late spring & $10.6 \pm 1.1 \mathrm{~b}$ & $12.9 \pm 1.2 \mathrm{~b}$ \\
\hline Late summer & $25.6 \pm 0.9 \mathrm{c}$ & $52.4 \pm 1.4 \mathrm{c}$ \\
\hline Bamby & $187+260$ & 35 \\
\hline Lileja & $20.3 \pm 2.6 \mathrm{~b}$ & $40.7 \pm 7.0 \mathrm{~b}$ \\
\hline & & \\
\hline & & \\
\hline
\end{tabular}




\section{$1 \quad$ Figures}
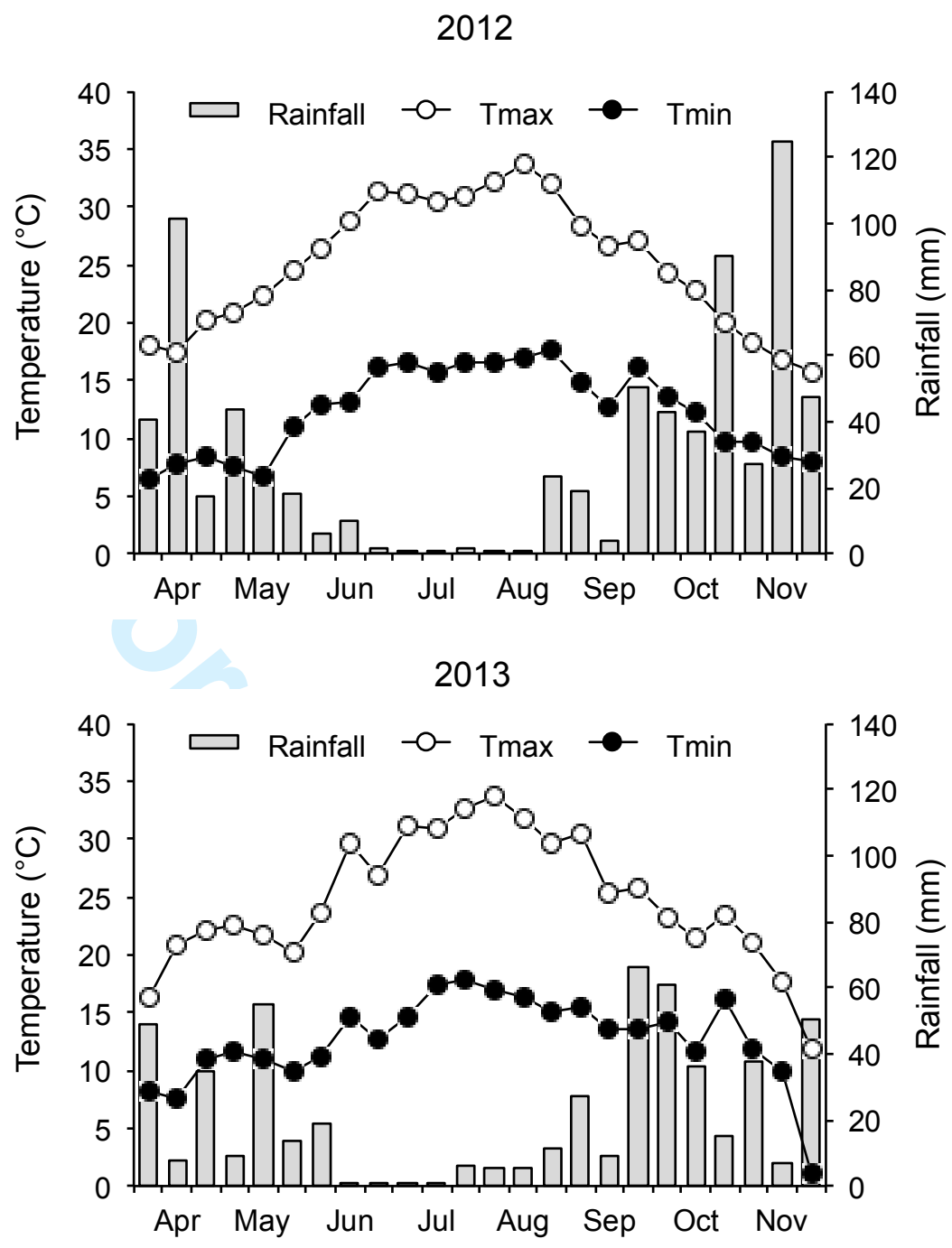

Fig. 1.

\section{5}



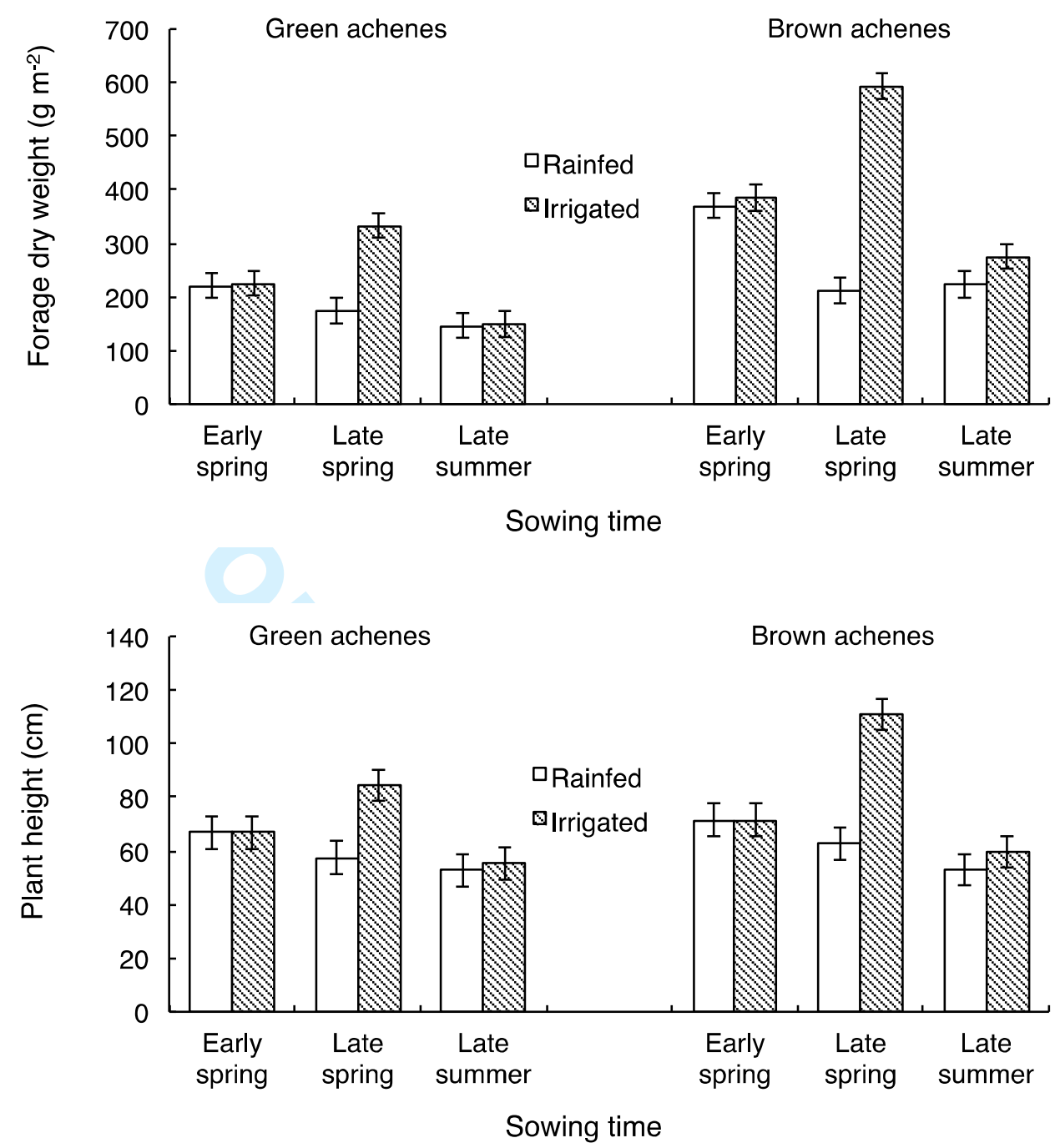

3

4 Fig. 2.

5

6 

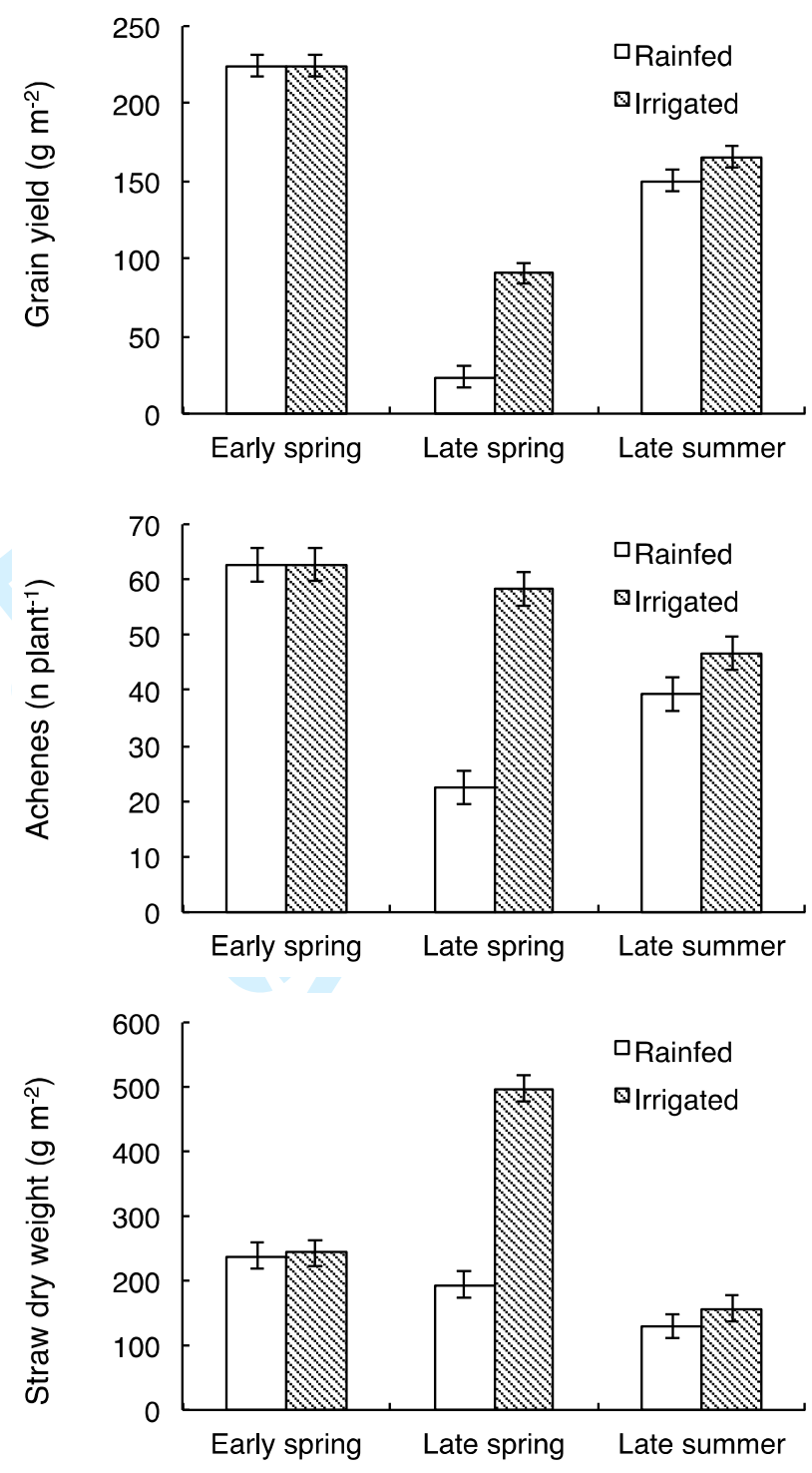

3

$4 \quad$ Fig. 3.

5

6 
Figure captions

5 Fig. 1. Decadic rainfall, and maximum and minimum temperatures over the research periods:

6 April-November 2012 and 2013.

7

8 Fig. 2. Forage dry weight and plant height of buckwheat at the first green and first brown

9 achenes stages, as affected by the sowing time $\mathrm{x}$ irrigation $\mathrm{x}$ stage of harvest interaction. Data

10 are the means of two years, two varieties and three replicates. Vertical bars represent LSD for $11 \quad \mathrm{P} \leq 0.05$.

12

13 Fig. 3. Grain yield, number of achenes per plant and straw dry weight of buckwheat at

14 maturity, as affected by the sowing time $\mathrm{x}$ irrigation interaction. Data are the means of two

15 years, two varieties and three replicates. Vertical bars represent LSD for $\mathrm{P} \leq 0.05$. 